\title{
Research on the Current Situation and Countermeasures of Poverty Alleviation by Baise Area County Compulsory Education in Southwest Border of China
}

\author{
Xingyu Li ${ }^{1}$, Wei Fang ${ }^{2}$, Xin Yuan ${ }^{2 *}$ \\ ${ }^{1}$ School of Educational Science, Baise University, Baise, China \\ ${ }^{2}$ Guangxi Baise Finance Bureau, Baise, China \\ Email: $59976205 @ q q . c o m$
}

How to cite this paper: Li, X. Y., Fang, W., \& Yuan, X. (2021). Research on the Current Situation and Countermeasures of Poverty Alleviation by Baise Area County Compulsory Education in Southwest Border of China. Open Journal of Social Sciences, 9, 157-166. https://doi.org/10.4236/jss.2021.912012

Received: October 17, 2021

Accepted: December 6, 2021

Published: December 9, 2021

Copyright ( 2021 by author(s) and Scientific Research Publishing Inc. This work is licensed under the Creative Commons Attribution International License (CC BY 4.0).

http://creativecommons.org/licenses/by/4.0/

\begin{abstract}
2020 is the year of decisive poverty alleviation, and wisdom must be first aided. At present, there are still problems such as inaccurate poverty alleviation and aid policies, and incomplete education precision poverty alleviation. It is worth studying how to improve the accuracy of education poverty alleviation. Achieving balanced development of compulsory education will be related to the realization of strategic goals such as rural rejuvenation, poverty alleviation, and the building of a well-off society in an all-round way. The balanced development of compulsory education at the county level in Guangxi is facing a new situation and ushering in new challenges. It is necessary to summarize and reflect on the balanced development of compulsory education in Guangxi in the new period. The research group takes the financial investment of compulsory education in the Baise region of the southwestern border of China as the research object, explores the balanced development status of compulsory education in Baise county through investigation and analysis, and seeks improvement measures in order to provide a certain reference for related decisions.
\end{abstract}

\section{Keywords}

Compulsory Education, Targeted Poverty Alleviation, Balanced Development

\section{Introduction}

The report of the Central Political and Economic Conference in 2019 pointed out that it is necessary to carry out poverty alleviation and poverty alleviation 
with precision, promote poverty alleviation through education, and let children in poor areas receive a good education. It is an important task of poverty alleviation and development and an important way to block intergenerational transmission of poverty. At present, there are still some problems in poverty alleviation through education, such as inaccurate policies for helping students and failure to achieve "full coverage". How to improve the accuracy of poverty alleviation through education deserves the attention of party committees and governments at all levels. As a basic public service, equality is the basic feature of compulsory education. Realizing the balanced development of compulsory education will be related to the realization of strategic goals such as rural revitalization, poverty alleviation and building a well-off society in an all-round way, which has important practical significance ( $\mathrm{Li} \& \mathrm{Li}, 2019$ ).

The balanced development of compulsory education at county level in Guangxi is facing a new situation and new challenges under the new economic normal background. It is particularly necessary to summarize and reflect rationally on the balanced development of compulsory education in Guangxi in the new period. Therefore, the research group takes Baise as the research object, discusses the balanced development of compulsory education in Baise county through investigation and analysis, and explores the improvement countermeasures. It is expected to attract more attention and provide a reference for relevant decisions.

\section{Research Design and Survey Implementation}

Randomly select 13 counties and districts in Baise City, and count their per-student expenditures, per-student school building area, per-student book volume, teacher-student ratio, etc., to evaluate the educational investment status of these counties, and provide a certain basis for educational poverty alleviation and poverty alleviation.

\section{Results}

\subsection{The Balanced Development of Baise Compulsory Education}

\subsubsection{Financial Input per Student}

It can be seen from Table 1 that in 2018, the per capita financial input of Baise City is 11,400 CNY, and the per capita financial input of Youjiang District, Tianyang County, Pingguo County and Longlin Autonomous County is lower than the overall level of Baise City. From the changing trend, from 2014 to 2018, the average financial input per student in Pingguo County decreased year by year, from $9700 \mathrm{CNY}$ to $8600 \mathrm{CNY}$, and the average financial input per student decreased by $1100 \mathrm{CNY}$. The financial input per student in other counties is increasing year by year, which is higher than the overall level of Baise City.

In 2018, the average financial input per student in Baise was 11,400 CNY, which was equal to the average financial input per student in compulsory primary education in the same period. Only Youjiang District, Tianyang County, 
Table 1. Financial input of primary and secondary school students in Baise county from 2014 to 2018 (10,000 CNY/person).

\begin{tabular}{|c|c|c|c|c|c|c|c|c|c|c|}
\hline & \multicolumn{2}{|c|}{2014} & \multicolumn{2}{|c|}{2015} & \multicolumn{2}{|c|}{2016} & \multicolumn{2}{|c|}{2017} & \multicolumn{2}{|c|}{2018} \\
\hline & $\begin{array}{l}\text { Primary } \\
\text { school }\end{array}$ & $\begin{array}{l}\text { Junior } \\
\text { school }\end{array}$ & $\begin{array}{l}\text { Primary } \\
\text { school }\end{array}$ & $\begin{array}{l}\text { Junior } \\
\text { school }\end{array}$ & $\begin{array}{l}\text { Primary } \\
\text { school }\end{array}$ & $\begin{array}{l}\text { Junior } \\
\text { school }\end{array}$ & $\begin{array}{l}\text { Primary } \\
\text { school }\end{array}$ & $\begin{array}{l}\text { Junior } \\
\text { school }\end{array}$ & $\begin{array}{l}\text { Primary } \\
\text { school }\end{array}$ & $\begin{array}{l}\text { Junior } \\
\text { school }\end{array}$ \\
\hline Baise City & 0.78 & 1 & 0.9 & 1.06 & 1.01 & 1.06 & 1.09 & 1.13 & 1.14 & 1.14 \\
\hline Baise city level & 1.13 & 1.3 & 0.54 & 0.93 & 1.78 & 4.09 & 1.98 & 1.8 & 2.1 & 1.16 \\
\hline Youjiang district & 0.9 & 0.99 & 0.97 & 1.1 & 1.15 & 1.2 & 1.11 & 1.36 & 1.1 & 0.99 \\
\hline Tianyang county & 0.95 & 1.08 & 0.95 & 1.58 & 1.16 & 1.16 & 1.14 & 1.08 & 0.98 & 0.95 \\
\hline Tiendong county & 0.77 & 0.94 & 1 & 1.06 & 1.01 & 0.91 & 1.2 & 1.14 & 1.28 & 1.16 \\
\hline Pingguo county & 0.97 & 1.33 & 0.93 & 1.02 & 0.93 & 0.86 & 0.84 & 0.89 & 0.86 & 0.9 \\
\hline Debao county & 1.02 & 1.03 & 1.32 & 1.16 & 1.36 & 1.35 & 1.45 & 1.27 & 1.24 & 1.14 \\
\hline Napo county & 0.69 & 0.78 & 1.12 & 1.04 & 1.22 & 1.02 & 1.02 & 1.02 & 1.23 & 1.51 \\
\hline Lingyun county & 1 & 1.01 & 0.89 & 0.98 & 1.01 & 1.03 & 1.11 & 1.23 & 1.16 & 1.15 \\
\hline Leye county & 0.65 & 1.08 & 0.79 & 0.83 & 1.25 & 1.17 & 1.27 & 1.2 & 1.51 & 1.42 \\
\hline Tianlin county & 0.57 & 0.93 & 0.73 & 1.12 & 0.81 & 0.95 & 1.06 & 1.2 & 1.22 & 1.27 \\
\hline Xilin xian & 0.59 & 1.26 & 0.73 & 2.06 & 0.92 & 1.48 & 1.1 & 1.79 & 1.43 & 2.15 \\
\hline $\begin{array}{l}\text { Multinational autonomous } \\
\text { county of longlin }\end{array}$ & 0.71 & 1.4 & 0.61 & 0.6 & 0.75 & 0.69 & 0.75 & 0.77 & 0.87 & 0.81 \\
\hline Jingxi county & 0.61 & 0.66 & 0.9 & 1.06 & 0.93 & 1.13 & 1.2 & 1.1 & 1.24 & 1.15 \\
\hline
\end{tabular}

Pingguo County and Longlin Autonomous County are lower than the overall level of Baise, while the other counties are higher than the overall level of Baise (Table 1). From 2014 to 2018, the overall financial investment for survival of Baise junior high schools showed an increasing trend, but the average financial investment of junior high schools in Baise City, Tianyang County and Longlin Autonomous County decreased.

\subsubsection{Average School Floor Area per Student}

The average campus area of Baise primary school students increased from 5.21 $\mathrm{m}^{2}$ in 2014 to $9.71 \mathrm{~m}^{2}$ in 2018 year by year, with an average increase of $4.5 \mathrm{~m}^{2}$ per student (Table 2). It should be noted that, contrary to the ever-increasing average school building area in other counties, the average school building area in Pingguo County has decreased from $8.41 \mathrm{~m}^{2}$ to $7.23 \mathrm{~m}^{2}$, a decrease of $1.18 \mathrm{~m}^{2}$.

It can be seen from Table 2 that the average school building area of Baise junior high school students is larger than that of primary schools. From 2014 to 2018, the average school building area of Baise junior high school increased by $10.65 \mathrm{~m}^{2}$ and $3.85 \mathrm{~m}^{2}$ year by year from $6.81 \mathrm{~m}^{2}$. In the past five years, the growth of the average school building area per student in Baise, Youjiang District, Tianyang County, Pingguo County, Debao County, Jingxi City and Xilin County are lower than the overall growth of Baise City. Therefore, the development of the average school area per student in Baise is unbalanced, so it is necessary 
Table 2. Average school area of primary and secondary school students in Baise county from 2014 to 2018 ( $\mathrm{m}^{2} /$ person).

\begin{tabular}{|c|c|c|c|c|c|c|c|c|c|c|}
\hline & \multicolumn{2}{|c|}{2014} & \multicolumn{2}{|c|}{2015} & \multicolumn{2}{|c|}{2016} & \multicolumn{2}{|c|}{2017} & \multicolumn{2}{|c|}{2018} \\
\hline & $\begin{array}{l}\text { Primary } \\
\text { school }\end{array}$ & $\begin{array}{l}\text { Junior } \\
\text { school }\end{array}$ & $\begin{array}{l}\text { Primary } \\
\text { school }\end{array}$ & $\begin{array}{l}\text { Junior } \\
\text { school }\end{array}$ & $\begin{array}{l}\text { Primary } \\
\text { school }\end{array}$ & $\begin{array}{l}\text { Junior } \\
\text { school }\end{array}$ & $\begin{array}{l}\text { Primary } \\
\text { school }\end{array}$ & $\begin{array}{l}\text { Junior } \\
\text { school }\end{array}$ & $\begin{array}{l}\text { Primary } \\
\text { school }\end{array}$ & $\begin{array}{l}\text { Junior } \\
\text { school }\end{array}$ \\
\hline Baise City & 5.21 & 6.81 & 6.92 & 9.8 & 7.85 & 9.96 & 8.86 & 11.25 & 9.71 & 10.65 \\
\hline Baise city level & 3.1 & 3.69 & 3.04 & 3.57 & 2.08 & 2.78 & 2.3 & 2.2 & 2.44 & 2.24 \\
\hline Youjiang district & 3.07 & 6.44 & 6.33 & 9.17 & 7.47 & 8.06 & 7.39 & 7.74 & 7.41 & 7.39 \\
\hline Tianyang county & 5.32 & 11.38 & 3.87 & 4.9 & 5.83 & 7.42 & 7.16 & 13.08 & 7.44 & 11.6 \\
\hline Tiendong county & 5.75 & 2.82 & 9.3 & 12.93 & 10.51 & 13.04 & 13.46 & 14.35 & 14.4 & 12.39 \\
\hline Pingguo county & 8.41 & 7.99 & 5.73 & 7.61 & 5.22 & 7.3 & 4.25 & 9.14 & 7.23 & 8.23 \\
\hline Debao county & 8.66 & 11.65 & 10.68 & 14.41 & 11.87 & 18.66 & 10.95 & 16.12 & 11.94 & 14.81 \\
\hline Napo county & 5.73 & 2.63 & 6.85 & 11.92 & 12.15 & 12.36 & 12.69 & 13.33 & 9.28 & 13.4 \\
\hline Lingyun county & 0.71 & 9.87 & 7.97 & 8.42 & 10.17 & 12.83 & 10.41 & 13.64 & 10.42 & 14.46 \\
\hline Leye county & 7.53 & 1.3 & 9.58 & 7.7 & 11.57 & 6.33 & 11.99 & 9.78 & 12.79 & 13.11 \\
\hline Tianlin county & 2.8 & 6.06 & 5.51 & 12.62 & 6.03 & 10.19 & 9.06 & 8.67 & 12.6 & 10.24 \\
\hline Xilin xian & 4.84 & 13.33 & 7.15 & 7.57 & 7.34 & 6.08 & 9.09 & 6.05 & 9.81 & 5.58 \\
\hline $\begin{array}{l}\text { Multinational autonomous } \\
\text { county of longlin }\end{array}$ & 5.9 & 3.09 & 5.01 & 11.64 & 4.91 & 10.58 & 5.06 & 14.58 & 6.58 & 12.49 \\
\hline Jingxi county & 2.74 & 8.17 & 7.46 & 10.44 & 7.51 & 12.51 & 10.48 & 13.09 & 10.5 & 11.03 \\
\hline
\end{tabular}

to increase investment to provide students with a high-quality education and learning environment.

\subsubsection{Books per Student}

From Table 3, it can be seen that with the increasing investment of school resources in Baise compulsory education in recent years, the per-student books in Baise primary schools are increasing, but the per-student books in Tiandong County and Longlin Autonomous County show a downward trend.

From Table 3, only junior high schools in Longlin Autonomous Region showed a decreasing trend from 2014 to 2018 , from 22.85 to $18: 22$, a decrease of 4.63 .

\subsubsection{Student-Teacher Ratio}

The student-teacher ratio of primary school students in Baise has gone through a process of first rising and then falling. Overall, the ratio of students to teachers in 2018 showed a downward trend compared with that in 2014. Baise City, Youjiang District, Tianyang County, Pingguo County, Tianlin County, Lingyun County, Longlin Autonomous County and Jingxi County are all higher than the average level of student-teacher ratio in Baise City. According to the changing trend, the ratio of students to teachers in Tiandong County, Napo County, leye county, Xilin County, Longlin Autonomous County and Jingxi County decreased every year between 2014 and 2018 (Table 4). 
Table 3. Books for primary and secondary school students in Baise County from 2014 to 2018 (books/person).

\begin{tabular}{|c|c|c|c|c|c|c|c|c|c|c|}
\hline & \multicolumn{2}{|c|}{2014} & \multicolumn{2}{|c|}{2015} & \multicolumn{2}{|c|}{2016} & \multicolumn{2}{|c|}{2017} & \multicolumn{2}{|c|}{2018} \\
\hline & $\begin{array}{l}\text { Primary } \\
\text { school }\end{array}$ & $\begin{array}{l}\text { Junior } \\
\text { school }\end{array}$ & $\begin{array}{l}\text { Primary } \\
\text { school }\end{array}$ & $\begin{array}{l}\text { Junior } \\
\text { school }\end{array}$ & $\begin{array}{l}\text { Primary } \\
\text { school }\end{array}$ & $\begin{array}{l}\text { Junior } \\
\text { school }\end{array}$ & $\begin{array}{l}\text { Primary } \\
\text { school }\end{array}$ & $\begin{array}{l}\text { Junior } \\
\text { school }\end{array}$ & $\begin{array}{l}\text { Primary } \\
\text { school }\end{array}$ & $\begin{array}{l}\text { Junior } \\
\text { school }\end{array}$ \\
\hline Baise City & 14.7 & 21.81 & 16.28 & 21.92 & 18.99 & 23.5 & 24.92 & 31.25 & 27.27 & 34.13 \\
\hline Baise city level & 9.38 & 10.28 & 9.23 & 10.12 & 9.03 & 11.68 & 10.73 & 15.83 & 13.22 & 16.4 \\
\hline Youjiang district & 16.79 & 19.26 & 16.51 & 17.09 & 15.64 & 16.42 & 25.94 & 26.55 & 31.37 & 39.47 \\
\hline Tianyang county & 8.93 & 44.04 & 10.33 & 27.69 & 20.58 & 37.35 & 25.17 & 42.62 & 29.61 & 36.79 \\
\hline Tiendong county & 21.93 & 22.55 & 18.43 & 22.23 & 18.29 & 19.74 & 19.2 & 38.04 & 18.13 & 32.45 \\
\hline Pingguo county & 15.45 & 11.63 & 14.7 & 17.36 & 13.69 & 16.81 & 26.35 & 20.65 & 25.07 & 24.09 \\
\hline Debao county & 17.39 & 27.5 & 27.14 & 37.37 & 30.51 & 40.83 & 27.03 & 35.19 & 24.5 & 35.45 \\
\hline Napo county & 17.24 & 24.77 & 20.89 & 28.99 & 20.04 & 16.62 & 21.85 & 25.37 & 21.46 & 25.7 \\
\hline Lingyun county & 13.83 & 24.4 & 18.72 & 24.84 & 32.72 & 39.75 & 35.23 & 44.74 & 35.07 & 41.98 \\
\hline Leye county & 17.82 & 24.33 & 20.13 & 19.53 & 33.36 & 36.34 & 33.74 & 43.07 & 35.96 & 45.5 \\
\hline Tianlin county & 19.43 & 16.66 & 9.16 & 19.45 & 9.75 & 15.95 & 16.64 & 20.64 & 36.64 & 43.6 \\
\hline Xilin xian & 8.89 & 21.2 & 13.14 & 21.71 & 17.67 & 23.38 & 18.49 & 29.29 & 28.59 & 37.19 \\
\hline $\begin{array}{l}\text { Multinational autonomous } \\
\text { county of longlin }\end{array}$ & 14.7 & 22.85 & 12.68 & 10.2 & 11.93 & 11.63 & 13.57 & 15.09 & 14.22 & 18.22 \\
\hline Jingxi county & 6.8 & 14.71 & 18.37 & 28.3 & 20.15 & 27.03 & 36.55 & 45.54 & 35.15 & 42.23 \\
\hline
\end{tabular}

Table 4. Teacher ratio of primary and secondary school students in Baise County from 2014 to 2018.

\begin{tabular}{|c|c|c|c|c|c|c|c|c|c|c|}
\hline & \multicolumn{2}{|c|}{2014} & \multicolumn{2}{|c|}{2015} & \multicolumn{2}{|c|}{2016} & \multicolumn{2}{|c|}{2017} & \multicolumn{2}{|c|}{2018} \\
\hline & $\begin{array}{l}\text { Primary } \\
\text { school }\end{array}$ & $\begin{array}{l}\text { Junior } \\
\text { school }\end{array}$ & $\begin{array}{l}\text { Primary } \\
\text { school }\end{array}$ & $\begin{array}{l}\text { Junior } \\
\text { school }\end{array}$ & $\begin{array}{l}\text { Primary } \\
\text { school }\end{array}$ & $\begin{array}{l}\text { Junior } \\
\text { school }\end{array}$ & $\begin{array}{l}\text { Primary } \\
\text { school }\end{array}$ & $\begin{array}{l}\text { Junior } \\
\text { school }\end{array}$ & $\begin{array}{l}\text { Primary } \\
\text { school }\end{array}$ & $\begin{array}{l}\text { Junior } \\
\text { school }\end{array}$ \\
\hline Baise City & 19.97 & 15.94 & 20.08 & 16.63 & 20.12 & 18.21 & 19.43 & 19.1 & 18.37 & 19.5 \\
\hline Baise city level & 20.72 & 18.49 & 20.95 & 18.38 & 26.89 & 15.79 & 25.39 & 18.53 & 24 & 17.26 \\
\hline Youjiang district & 17.13 & 17.57 & 18.01 & 18.01 & 18.69 & 20.23 & 18.82 & 21.44 & 19.64 & 23.97 \\
\hline Tianyang county & 21.58 & 11.56 & 22.26 & 12.8 & 22.57 & 12.96 & 24.35 & 15.34 & 22.38 & 17.01 \\
\hline Tiendong county & 18.64 & 12.48 & 18.93 & 13.01 & 18.5 & 17.05 & 18.45 & 17.83 & 16.77 & 18.87 \\
\hline Pingguo county & 18.2 & 15.12 & 19.15 & 16.01 & 20.08 & 15.83 & 19.45 & 17.58 & 19.85 & 17.99 \\
\hline Debao county & 17.59 & 15.14 & 17.62 & 15.18 & 17.58 & 16.93 & 17.63 & 17.75 & 17.61 & 17.48 \\
\hline Napo county & 19.84 & 14.56 & 18.39 & 15.83 & 18.88 & 15.61 & 17.82 & 15.95 & 18.36 & 17.43 \\
\hline Lingyun county & 17.43 & 15.06 & 21.85 & 20.82 & 20.77 & 22.64 & 19.51 & 21.75 & 18.87 & 22.1 \\
\hline Leye county & 22.15 & 20.73 & 15.75 & 15.9 & 14.29 & 14.93 & 14.39 & 13.93 & 12.55 & 13.33 \\
\hline Tianlin county & 16.53 & 16.68 & 22.56 & 18.26 & 21.7 & 22.17 & 20.66 & 26.94 & 18.9 & 28.91 \\
\hline Xilin xian & 22.46 & 16.69 & 22.87 & 19.23 & 21.06 & 23.01 & 18.51 & 21.06 & 16.91 & 22.05 \\
\hline $\begin{array}{l}\text { Multinational autonomous } \\
\text { county of longlin }\end{array}$ & 24.13 & 18.49 & 25.3 & 23.4 & 24.98 & 25.41 & 22.8 & 24.79 & 18.67 & 24.06 \\
\hline Jingxi county & 26.18 & 21.72 & 19.42 & 15.2 & 20.98 & 17.25 & 19.28 & 17.89 & 18.57 & 16.5 \\
\hline
\end{tabular}


According to the data in 2018, the ratio of teachers to junior high school students in Baise is 19.5:1, which is higher than that in primary school. From 2014 to 2018, the ratio of students to teachers in Baise, leye county and Jingxi decreased to some extent. The ratio of students to teachers in other counties has increased year by year (Table 4).

\section{Main Problems}

\subsection{The Object of Poverty Alleviation Is Not Accurate Enough}

The existing policies for helping the poor, such as "three exemptions and one subsidy", nutritious meals for students, subsidies for boarding students in difficulties, etc., lack precision, are inclusive, and the standards are not high (Wen \& Xue, 2019). Some of them are not poor students who have set up their cards, and their support is too large, resulting in less per capita aided resources.

\subsection{Poor Infrastructure and Serious Brain Drain in Schools in Poor Villages}

Most village-level schools are short of equipment, weak in infrastructure, and poor in supporting facilities such as education, living rooms and sports venues. At the same time, due to the inconvenient transportation, poor treatment and poor working conditions of many mountain village schools, young teachers are reluctant to teach in schools in these areas (Ma, 2018). From 2014 to 2016, Baise cities and counties recruited 420 teachers through recruitment and public examinations. However, 79 teachers were lost in the past three years, which seriously affected the education and teaching in rural schools.

\subsection{The Allocation and Distribution of Educational Resources Are Not Balanced}

Overall, the development of compulsory education in Baise county is still unbalanced. Specifically, from the perspective of school building construction, although the school building area in Baise is increasing year by year, the average school building area per student in different regions is different. From the perspective of teachers' strength, the number of teachers in Baise is in short supply, while the county teachers' strength is weak. Judging from the number of books. In 2018, the gap between primary school students and junior high school students in Baise reached 23.42 and 29.1 respectively, reflecting the unbalanced distribution of resources and insufficient investment in Baise compulsory education and the shortage of teaching resources. From the perspective of financial input per student, the investment of financial funds for education in Baise cities and counties is increasing year by year, and the financial situation of education is showing a good momentum. However, the difference between the highest and lowest financial input per student in primary school and county reached 12,400 CNY, and the difference between the highest and lowest financial input per student in middle school was $13,400 \mathrm{CNY}$. 


\section{Countermeasures and Suggestions}

\subsection{Implementing the Detailed Rules of the State for Implementing Education and Poverty Alleviation at Different Levels}

1) In view of the phenomenon of "marginal poverty" and the objective reality that there will be some errors in the process of setting up a card for poor households, the reform will be deepened from top to bottom, from the autonomous region to the grass-roots level, the rules of precise education for poverty alleviation will be refined, the particularity, objectivity and unity of local operations will be standardized, and the education equity in poverty-stricken areas will be truly realized on the basis of balanced development (Wang \& Hu, 2019).

2) Standardize the use of funds while improving the quality of financial personnel in primary and secondary schools.

First, strengthen the system construction and standardize the use of funds. Establish and improve the supervision system for the listing of school responsible inspectors and the supervision and accountability mechanism for the balanced development of compulsory education, and take the school standardization construction, campus culture construction and routine management as the key points of regular supervision of responsible inspectors, while government inspectors strengthen the special supervision for balanced development work (Wang \& $\mathrm{Hu}, 2019)$. At the same time, the financial, auditing, education and other departments of the district strengthened supervision and inspection and guidance, organized various special inspections, implemented the spirit of the "eight regulations", supported students, further standardized the use of funds, and strengthened supervision of funds.

Second, strengthen the financial management of rural primary and secondary schools and improve the overall quality of financial managers. In order to rationally use funds and improve the efficiency of rural compulsory education funds, strengthening the financial management of rural primary and secondary schools is the key. Formulate relevant policies to bring the construction of accounting team in rural primary and secondary schools into the scope of school development plan. Each school is equipped with professional financial management personnel, and strengthens the training of financial managers aiming at improving their professional quality, so as to provide a powerful guarantee for the rational use of funds and the improvement of the use efficiency of rural compulsory education funds.

\subsection{The Need for the Autonomous Region to Increase Support in Terms of Policies, Funds and Projects}

Focus on education in poverty-stricken counties, give priority to supporting poverty-stricken villages, comprehensively improve their basic conditions for running schools, and narrow the gap between them and developed areas (Okwuwa, 2019), so that children in poverty-stricken areas can enjoy fair and high-quality 
educational resources nearby.

1) Continuing to increase investment in Baise compulsory education.

In the final analysis, the unbalanced development of compulsory education in counties (cities and districts) is the unbalanced investment in education funds. We should further increase the investment in Baise compulsory education, improve the conditions for running schools, and upgrade the standards of software and hardware construction. However, Baise, as an "old, small, marginal, poor and poor" region, has relatively backward economic development and limited financial self-sufficiency. As an important starting point for precise poverty alleviation, education also provides an effective guarantee for the balanced development of county compulsory education in Baise City. It is necessary for the central government and the finance of the autonomous region to bear more expenditure responsibilities, further increase the allocation of special funds for compulsory education in Baise, and give more support to Baise education in the practice of tackling difficulties in the balanced development of compulsory education. Free each school from financial anxiety, and concentrate on improving and enhancing the teaching quality. At the same time, special funds will be arranged to vigorously support the basic education capacity building in poverty-stricken areas and old revolutionary areas, expand the scope of living allowance and nutrition improvement plan for boarding students in rural compulsory education in Baise, and ensure that compulsory education schools have no new debts. It should narrow the gap between Baise compulsory education and advanced developed areas, and effectively improve the standardization level of each school.

2) Optimize the allocation of educational resources and strengthen infrastructure construction.

First, continue to strengthen the government's overall responsibility. It is necessary to continuously strengthen the county government's performance of educational duties, continue to strengthen the leadership of promoting the balanced development of compulsory education, intensify overall planning, and coordinate the cooperation among various functional departments, so as to provide a strong guarantee for the balanced development of compulsory education with high quality on the basis of achieving basic balance.

Second, further strengthen infrastructure construction. Accelerate the project construction and make up the shortcomings of education. First, speed up the land acquisition task of newly built (relocated), renovated and expanded project schools, especially the land for newly built, renovated and expanded schools. Second, accelerate the pace of building new, renovated and expanded schools, improve the area standards of education, teaching and auxiliary rooms, and expand sports venues. Solve the problems of large classes and insufficient sports venues in schools. Third, speed up the bidding and purchasing of teaching materials and books, make up for the shortage of books, computers and teaching materials in schools in terms of quantity and quality as soon as possible, and im- 
prove the equipment level of schools. Fourth, continue to vigorously transform the infrastructure of weak schools in rural compulsory education, repair the existing available school buildings, and promote the rural teacher support program. All compulsory education funds give priority to ensuring the funding needs of weak schools in rural areas (Shao \& Zhou, 2019).

Third, make every effort to promote counterpart assistance between urban and rural areas. In order to make up the shortcomings, allocate teachers' resources in urban and rural areas in a balanced way, and implement the urban-rural pairing assistance mode, backbone teachers are organized to send to the countryside irregularly every semester to exchange and learn from each other, so as to improve the overall quality of teachers. It should establish a system of supporting teachers in county schools in the countryside, let the teaching teachers enjoy the priority of job title evaluation, job promotion, post setting and evaluation, and encourage teachers to communicate in the countryside (Gao \& Wang, 2018).

Fourth, accelerate the pace of information construction. Improve the educational information infrastructure, jointly build and share high-quality digital educational resources, deeply integrate information technology with education and teaching, and scientifically develop the educational information mechanism. High-quality teaching resources will fully cover rural schools, helping rural schools, especially teaching points, to open full courses and promote the balanced development of regional education (Gao \& Wang, 2018).

\subsection{To Strengthen the Construction of Teachers in Poor Areas}

We will continue to implement the directional training plan at the autonomous region level, and train a group of outstanding normal students who are mainly born from poor families in rural areas. Every year, a group of excellent teachers from urban schools are selected to teach in weak rural schools. Improve the treatment of teachers in poor rural schools and strictly implement the subsidy policy for teachers in remote mountainous areas. Implement the performance reward mechanism for schoolteachers in poverty-stricken areas. Villages and towns with conditions can build public rental housing for rural school teachers near the township, changing the current situation that young teachers can't stay (Li \& Yang, 2021).

\section{Funding}

Baise University Teaching Reform Project (NO. 2019JG42); Guangxi Zhuang Autonomous Region Higher Education Reform Project of China (No. 2019JGB351).

\section{Conflicts of Interest}

The authors declare no conflicts of interest regarding the publication of this paper.

\section{References}

Gao, D. Y., \& Wang, W. F. (2018). A Preliminary Study of Information Technology Ac- 
curately Helping Compulsory Education in Poor Areas. Education Modernization, 5, 173-174.

Li, B., \& Yang, H. Z. (2021). Research on the Predicament and Countermeasures of Targeted Poverty Alleviation in Deeply Poverty Mountainous Areas-Taking Shangzhou District of Shangluo City as an Example. Journal of Agricultural Sciences, 11, 124-130.

Li, X. Q., \& Li, Q. (2019). An Empirical Test of the Equilibrium of Compulsory Education in China from 2005 to 2015-Based on the Perspective of Per Student Funds. Education Science, 35, 67-74.

Ma, C. Y. (2018). Strengthen Compulsory Education and Targeted Poverty Alleviation. China Economic and Trade Guide, No. 10, 38-39.

Okwuwa, C. O. (2019). The Imperative of Repositioning Nigeria's Development Initiative through Agriculture, the Neglected Path. Advances in Social Sciences Research Journal, 6, 250-264. https://doi.org/10.14738/assrj.65.6485

Shao, X., \& Zhou, W. (2019). A Review of Research on Precision Poverty Alleviation in Compulsory Education. Journal of Anshun University, 21, 23-26.

Wang, M. D., \& Hu, S. L. (2019). Research on the Balanced Development of Compulsory Education in Guangxi under the Background of Targeted Poverty Alleviation. Education Teaching Forum, No. 15, 90-92.

Wen, Y., \& Xue, J. (2019). Research on the Efficiency of China's Urban and Rural Compulsory Education Financial Investment under the Background of Rural Revitalization Strategy. Education and Economy, No. 3, 56-64. 